\title{
Upaya Meningkatkan Prestasi Belajar Agama Hindu Melalui Penggunaan Model Pembelajaran Quick On The Draw
}

\author{
Ni Nyoman Sumerti ${ }^{1}$ \\ 1SD Negeri 2 Siangan, \\ Gianyar, Indonesia \\ email: ninyomansumerti12@gmail.com
}

\begin{abstract}
Abstrak
Tujuan melakukan penelitian tindakan kelas ini adalah untuk meningkatkan prestasi belajar Agama Hindu siswa Kelas VI SD Negeri 2 Siangan pada semester I. Subjek penelitian ini adalah siswa Kelas VI SD Negeri 2 Siangan. Cara yang dilakukan adalah menambah gaya pembelajaran lama yang konvensional menjadi cara pembelajaran baru yang bersifat penemuan menggunakan model pembelajaran Quick On The Draw. Penelitian dilakukan dalam dua siklus yang masing-masing siklusnya dilakukan dengan tahap poerencanaan, pelaksanaan, observasi, dan refleksi. Untuk mengumpulkan data hasil penelitian digunakan tes prestasi belajar dan untuk menganalisis datanya digunakan analisis deskriptif. Dilihat dari hasil evaluasi yang telah dilakkukan terjadi peningkatan dari data awal dengan rata-rata 69,00 , ketuntasan belajar 43,33\%. Pada siklus I rata-ratanya 74,33 meningkat menjadi 82,66 pada siklus II dengan ketuntasan belajar 93,33\%. Dengan demikian dapat disampaikan simpulan bahwa penerapan model Quick On The Draw dapat meningkatkan prestasi belajar Agama Hindu siswa kelas VI semester I SD Negeri 2 Siangan.
\end{abstract}

Kata Kunci: Prestasi Belajar Agama Hindu, Model Quick on The Draw.

\begin{abstract}
The purpose of conducting this classroom research is to improve the learning achievement of Hindu students of Class VI SD Negeri 2 Siangan in the first semester. The subjects of this study were students of Class VI SD Negeri 2 Siangan. The way this is done is to add the old conventional learning style to a new way of learning related to the use of the Quick On The Draw learning model. The research was conducted in two cycles, each of which was carried out with the stages of planning, implementing, observing, and reflecting. To collect research data used, learning achievement and to analyze the data used descriptive analysis. Judging from the results of the evaluation, there has been an increase in the increase from the initial data with an average of 69.00 , learning completeness $43.33 \%$. In the first cycle the internal average of 74.33 increased to 82.66 in the second cycle with $93.33 \%$ completeness learning. Thus it can be concluded that the application of the Quick On The Draw model can improve the learning achievement of Hindu students in grade VI semester I SD Negeri 2 Siangan.
\end{abstract}

Keywords: Hindu Learning Achievement, Quick On The Draw model.

\section{Pendahuluan}

Paradigma pendidikan Indonesia dewasa ini mengalami pergeseran yakni mengajar bukan lagi usaha untuk menyampaikan ilmu pengetahuan, melainkan juga usaha menciptakan system lingkungan yang membelajarkan subjek didik agar tujuan pengajaran dapat tercapai secara optimal. Mengajar dalam pemahaman ini memerlukan suatu strategi pembelajaran yang efektif. Mutu pengajaran tergantung pada pemilihan strategi yang tepat dalam upaya mengembangkan kreativitas, kemampuan, dan sikap inovatif peserta didik. Untuk itu perlu dibina dan dikembangkan kemampuan professional guru untuk mengelola program pengajaran dengan strategi pembelajaran yang kaya dengan variasi.

Untuk bisa menyelesaikan dan merubah individu agar takwa terhadap Tuhan Yang Maha Esa tidaklah gampang. Hal tersebut harus dilakukan lewat pembiasaan dan dilakukan dengan sangat gigih dalam pembelajaran. Usaha untuk tersebut tentu harus dibarengi dengan

\footnotetext{
*Corresponding author.

Received 03 Februari 2020; Accepted 31 July 2020; Available online 1 September 2020

(C) 2020 MPI. All Rights Reserved
} 
penanaman pengertian-pengertian, pengetahuan-pengetahuan, pemahaman-pemahaman serta dilakukan dengan sungguh-sungguh.

Dalam dunia pembelajaran dikenal adanya beberapa hal penting seperti media, metode, model, strategi, pendekatan dan teknik. Hal-hal tersebut mempunyai tujuan akhir yakni guna mencapai peningkatan dalam proses belajar mengajar. Dengan guru mampu melakukan pemilihan dan penggunaan hal-hal tersebut akan dapat mencapai hasil-hasil yang maksimal dari kegiatan belajar mengajar.

Masalah yang sedang dihadapi saat ini di Kelas VI di SD Negeri 2 Siangan betul-betul merupakan masalah pembelajaran dimana siswa di kelas ini belum aktif belajar. Maka masih menunggu perintah guru, masih kebiasaan dengan proses pengajaran yang konvensional yang memang penyebabnya adalah di pihak guru yang mengajar seperti itu. Guru belum mampu membuat peserta didik agar mampu menemukan sendiri seuai prinsip pembelajaran masa kini. Proses pembelajaran yang yang dilakukan guru berhari-hari sama saja seperti itu. Hal inilah yang menjadi masalah sehingga peningkatan mutu pendidikan belum dapat diupayakan lebih maksimal.

Guna mencapai hasil oleh kreativitas yang maksimal, maka guru dituntut agar lebih tepat dalam menulis dan menentukan media, metode, model, strategi, pendekatan dan teknik yang digunakan dalam melaksanakan proses belajar mengajar. Yang tidak kalah penting juga adalah dikuasai atau tidaknya materi pelajaran yang diajar, dengan kata lain sebagai guru ternyata ada tuntutan untuk berolah kreatifitas secara langsung di hadapan siswa.

Ketersediaan waktu di sekolah untuk memperbaiki proses belajar mengajar menyebabkan peneliti melakukan penelitian yang berjudul"Meningkatkan Prestasi Belajar Agama Hindu Melalui Penggunaan Model Pembelajaran Quick On The Draw Siswa Kelas VI SD Negeri 2 Siangan Semester I Tahun Pelajaran 2018/2019". Dalam upaya memecahkan permasalahan yang penting dan mendesak di kelas ini. Selain ketersediaan waktu juga memilliki dana untuk menyelesaikan karya ini akibat dengan adanya dukkungan yang memadai yang tersedia di sekolah ini.

Pelaksanaan proses pembelajaran menggunakan model tradisional atau konvensional belum membuahkan hasil sesuai harapan. Oleh karenanya penulis mulai memikirkan cara untuk memecahkan masalah yang mendesak untuk ditangani. Prestasi belajar siswa Kelas VI di SD Negeri 2 Siangan pada semester I masih jauh di bawah KKM pada mata pelajaran Agama Hindu di sekolah ini yaitu 75. Rata-rata yang diperoleh baru 68,87 dan ketuntasan belajar mereka baru mencapai $41,93 \%$. Perolehan hasil yang rendah tersebut merupakan masalah yang sesegera mungkin harus ditangani, itulah yang mendorong peneliti sehingga penelitian ini menjadi penting untuk dilaksanakan.

\section{Metode Penelitian}

Penelitian yang dilaksanakan di SD Negeri 2 Siangan termasuk penelitian tindakan kelas. Dalam Penelitian Tindakan rancangan didesain dalam bentuk siklus dengan pemberian tindakan. Penelitian ini akan dilaksanakan dalam dua siklus yang setiap siklusnya terdiri dari tiga kali pertemuan untuk memberikan tindakan.

Dalam melaksanakan penelitian, rancangan merupakan hal yang sangat penting untuk disampaikan. Untuk maksud tersebut, penelitimenggunakan rancangan siklus penelitian tindakan yang disampaikan oleh Arikunto Suharsimi 2007 terlihat pada gambar di bawah ini. 


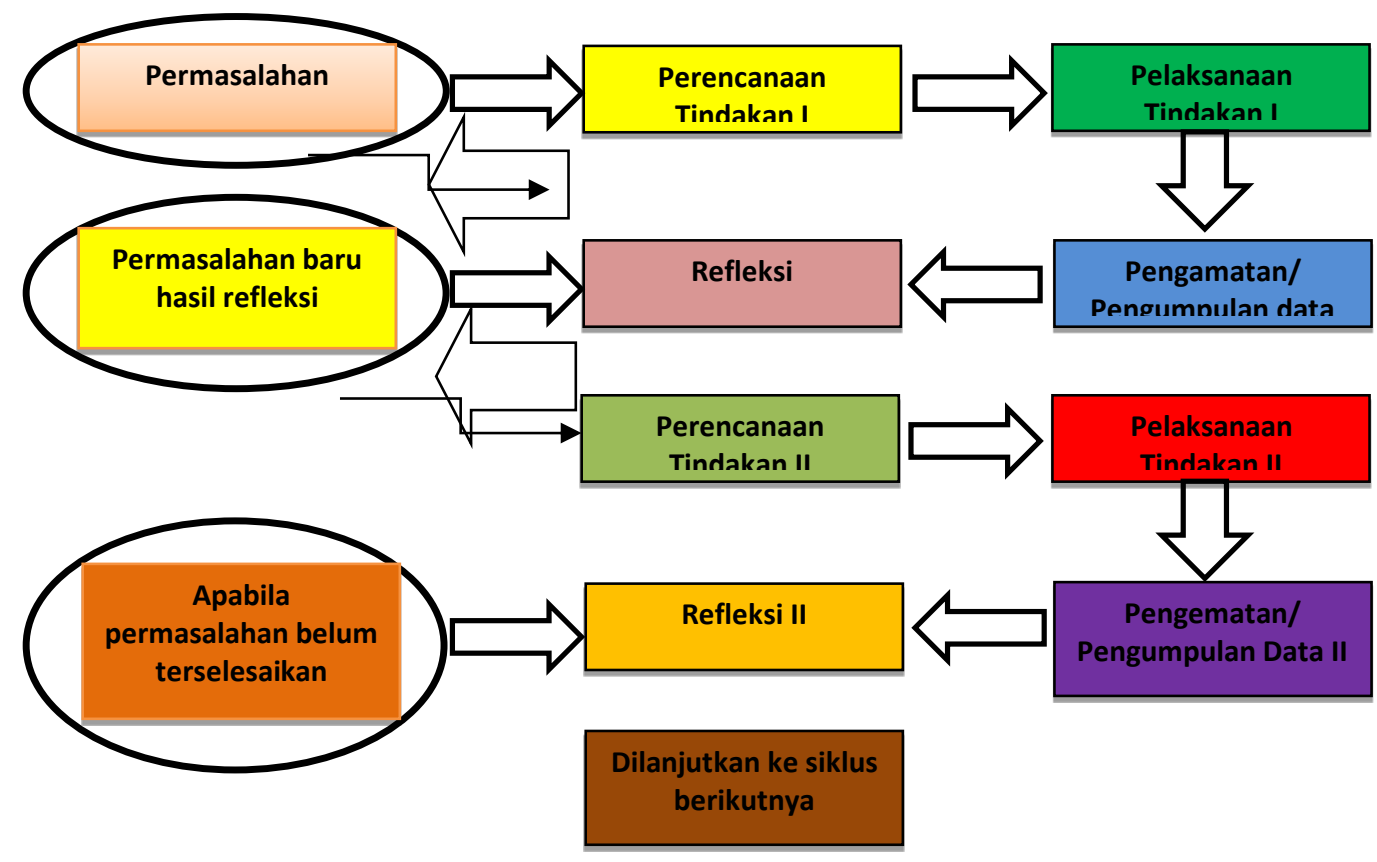

Gambar: 01 Alur Penelitian Tindakan Kelas (dalam Suharsimi Arikunto, Suhardjono, Supardi, 2006: 74)

\section{Perencanaan}

Pada tahap ini peneliti membuat RPP, berkonsultasi dengan teman sejawat membuat instrumen. Pada tahap menyusun rancangan diupayakan ada kesepakatan antara guru dan sejawat. Rancangan dilakukan bersama antara peneliti yang akan melakukan tindakan dengan guru lain yang akan mengamati proses jalannya tindakan. Hal tersebut untuk mengurangi unsur subjektivitas pengamat serta mutu kecermatan pengamatan yang dilakukan.

\section{Pelaksanaan Tindakan}

Tahap pelaksanaan tindakan dilakukan dengan pembelajaran di kelas. Pada tahap ini guru peneliti giat melakukan tindakan menggunakan model pembelajaran Quick On The Draw. Rancangan tindakan tersebut sebelumnya telah dilatih untuk dapat diterapkan di dalam kelas sesuai dengan skenarionya. Skenario dari tindakan diupayakan dilaksanakan dengan baik dan wajar.

\section{Pengamatan atau observasi}

Tahap ini sebenarnya berjalan bersamaan dengan saat pelaksanaan. Pengamatan dilakukan pada waktu tindakan sedang berjalan, jadi, keduanya berlangsung dalam waktu yang sama. Pada tahap ini, guru yang bertindak sebagai peneliti melakukan pengamatan dan mencatat semua hal yang diperlukan dan terjadi selama pelaksanaan tindakan berlangsung. Pengumpulan data ini dilakukan dengan menggunakan tes prestasi belajar yang telah tersusun, termasuk juga pengmatan secara cermat pelaksanaan skenario tindakan dari waktu ke waktu serta dampaknya terhadap proses dan hasil belajar siswa.

\section{Refleksi}

Tahapan ini dimaksudkan untuk mengkaji secara menyeluruh tindakan yang telah dilakukan, berdasarkan data yang telah terkumpul, kemudian dilakukan evaluasi guna menyempurnakan tindakan berikutnya. 
Refleksi dalam PTK mencakup analisis, sintesis, dan penilaian terhadap hasil pengamatan atas tindakan yang dilakukan. Jika terdapat masalah dari proses refleksi maka dilakukan proses pengkajian ulang melalui siklus berikutnya yang meliputi kegiatan: perencanaan ulang, tindakan ulang, dan pengamatan ulang shingga permasalahan dapat teratasi.

Pengumpulan data dalam penelitian ini menggunakan tes prestasi belajar. Tes prestasi belajar berupa tes soal isian maupaun esay. Untuk menganalisis data hasil penelitian ini digunakan metode deskriptif. Untuk data kuantitatif dianalisis dengan mencari mean, median, modus, membuat interval kelas dan melakukan penyajian dalam bentuk tabel dan grafik.

Indikator keberhasilan penelitian yang diusulkan dalam penelitian ini pada siklus I dan II mencapai nilai rata-rata 75,00 dengan ketuntasan belajar $85 \%$. dengan KKM yang ditetapkan untuk mata pelarajan Agama Hindu pada SD Negeri 2 Siangan adalah 75.

\section{Hasil Dan Pembahasan}

Hasil tes prestasi belajar yang merupakan tes isian dan esay memforsir siswa untuk betul-betul dapat memahami apa yang sudah dipelajari. Nilai rata-rata siswa di siklus I sebesar 74,33 menunjukkan bahwa siswa setelah menguasai materi yang diajarkan walaupun belum begitu sempurna. Hasil ini menunjukkan peningkatan kemampuan siswa menguasai mata pelajaran Agama Hindu Apabila dibandingkan dengan nilai awal siswa sesuai data yang sudah disampaikan dalam analisis sebelumnya.

Hasil tes prestasi belajar di siklus I telah menemukan efek utama bahwa penggunaan model tertentu akan berpengaruh terhadap prestasi belajar siswa yang dalam hal ini adalah model Quick On The Draw Hal ini sesuai dengan hasil meta analisis metode pembelajaran yang dilakukan oleh Soedomo, 1990 (dalam Puger, 2004) yang menyatakan bahwa model/metode pembelajaran yang diterapkan oleh seorang guru berpengaruh terhadap prestasi belajarnya.

Seperti telah diketahui bersama bahwasannya mata pelajaran Agama Hindu menitikberatkan pembelajaran pada aspek kognitif, afektif, dan psikimotorik sebagai pedoman prilaku kehidupan sehari-hari siswa. Untuk penyelesaian kesulitan yang ada maka penggunaan model ini dapat membantu siswa untuk bertindak aktif, keratif,inovatif, dan mandiri. memecahkan masalah yang ada bersama dengan anggota kelompok diskusinya. Hal inilah yang membuat siswa berpikir lebih tajam, lebih kreatif dan kritis sehingga mampu untuk memecahkan masalah-masalah yang kompleks dan efek selanjutnya adalah para siswa akan dapat memahami dan meresapi mata pelajaran Agama Hindu lebih jauh.

Kendala yang masih tersisa yang perlu dibahas adalah prestasi belajar yang dicapai pada siklus I ini belum memenuhi harapan sesuai dengan tuntutan KKM mata pelajaran Agama Hindu di sekolah ini yaitu 75. Oleh karenanya upaya perbaikan lebih lanjut masih perlu diupayakan sehingga perlu dilakukan perencanaan yang lebih matang untuk siklus selanjutnya.

Hasil yang diperoleh dari tes prestasi belajar di siklus II menunjukkan bahwa kemampuan siswa dalam mengikuti pelajaran sudah cukup baik. Ini terbukti dari rata-rata nilai siswa mencapai 82,66. Hasil ini menunjukkan bahwa model Quick On The Drawd telah berhasil meningkatkan prestasi belajar bidang studi Agama Hindu siswa kelas VI.

Hasil penelitian ini membuktikan bahwa model/metode yang diterapkan dalam proses pembelajaran berpengaruh secara signifikan terhadap prestasi belajar siswa. Prestasi yang dicapai siswa membuktikan bahwa guru sudah tepat memilih model/metode dalam melaksanakan proses pembelajaran.

Setelah dilakukan tindakan dalam dua siklus dapat dilihat perbandingan nilai rata-rata yang diperoleh, dimana pada awalnya nilai rata-rata siswa hanya 69,00 naik di siklus I menjadi 74,33 dan di siklus II naik menjadi 82,66. Kenaikan ini merupakan upaya maksimal yang peneliti laksanakan untuk meningkatkan prestasi belajar siswa terutama meningkatkan mutu pendidikan di SD Negeri 2 Siangan.

Hasil penelitian ini sesuai dengan hasil penelitian yang dikemukakan oleh Ayu, dkk (2018) dengan judul Penerapan Pembelajaran Quick On The Draw Padamateri Laju Reaksi 
Untuk Meningkatkan Aktivitas Belajar Siswa. Dari hasilanalisa data diketahuibahwaaktivitas belajar peserta didik meningkat dari siklus I ke siklus II dan berada pada kriteria baik dan sangat baik. Pada siklus 1 diperoleh rata-rata minat peserta didik secara klasikal yaitu 13,77 dan pada siklus ke II meningkat menjadi 19,06 dengan presentase aktivitas belajar pada siklus I yaitu $57,36 \%$ dan meningkat secara signifikan pada siklus II menjadi 79,43\% . Penerapan model pembelajaran kooperatif tipe Quick On The Draw dapat meningkatkan aktivitas belajar kimia siswa kelas XI MIA 4 SMAN 1 Pekanbaru.

Selanjutnya penelitian yang dilakukan oleh Lestiyaningsih (2013) dengan judul Penerapan Pembelajaran Quick On The Draw Untuk Meningkatkan Hasil Belajar Matematika Pada Sub Pokok Bahasan Aritmetika Sosial Siswa Kelas VII F Semester Ganjil SMP Negeri 10 Jember Tahun Ajaran 2012/2013. dalam penelitianya dinyatakan bahwa: penerapan pembelajaran Quick On The Draw dapat meningkatkan hasil belajar matematika pada Sub Pokok Bahasan Aritmetika Sosial Siswa Kelas VII F Semester Ganjil SMP Negeri 10 Jember tahun ajaran 2012/2013.

Penelitian yang dilakukan oleh Sthephani (2017) dengan judul Penerapan Model Kooperatif Dengan Teknik Quick On The Draw Untuk Meningkatkan Hasil Belajar Matematika Siswa Kelas VII5 SMP Negeri 22 Pekanbaru. Hasil penelitian berdasarkan pengamatan peneliti selama proses pembelajaran berlangsung, aktivitas dan interaksi siswa dalam kelompok sangat baik, siswa lebih bersemangat dan aktif dalam proses pembelajaran. Sedangkan berdasarkan ketercapaian KKM hasil belajar matematika siswa menunjukan peningkatan siswa yang mencapai KKM dibandingkan hasil belajar pada materi pokok sebelumnya. Hal ini dapat terlihat dari siswa yang mencapai KKM pada UH I 55,56\% dan UH II 63,89\% sedangkan pada materi sebelumnya siswa yang mencapai KKM 47,22\%. Sedangkan yang menjadi kendala dan hambatan dalam penerapan model pembelajaran kooperatif dengan teknik Quick On The Draw di kelas VII5 SMP N 22 Pekanbaru adalah kurangnya memperhitungkan waktu oleh peneliti sehingga ada pelaksanaan tindakan yang tidak dapat terlaksanakan dengan baik, adapun siswa yang belum terbiasa dengan penerapan model pembelajaran kooperatif dengan teknik Quick On The Draw.

\section{Simpulan}

Hasil yang diperoleh dari penelitian ini bahwa model Quick On The Draw dapat memberi jawaban sesuai tujuan penelitian ini. Semua ini dapat dicapai karena model Quick On The Draw sangat efektif diterapkan dalam proses pembelajaran yang mengakibatkan siswa aktif, antusias dan dapat memahami materi yang diajarkan sehingga prestasi belajar siswa menjadi meningkat.

\section{Daftar Pustaka}

Adnyani, Nyoman. 2002. Kelemahan-kelemahan Peneriman Siswa SMP yang Beracuan pada NUAN. Makalah yang Disampaikan dalam Seminar Ilmiah Universitas Mahasaraswati, Septermber 2003.

Alien, Deborah .et-al 1996. The Power of Problem Based Learning in Teaching Introductory Science Courses. Jossey-Boss Publisher.

Amien, Moh. 1996. Perkembangan Intelektual Siswa SMP. Jurnal IImu Pendidikan. Jilid 3 No. 4. Jakarta: LTPTK dan ISP.

Anastasi, Anne. 1976. Psychological Testing. Fifth Edition. New York: Macmillan Publishing Co., Inc.

Anom. 2000. Profesionalisme Guru Fisika dalam Menghadapi Tantangan Era Global. Makalah. Disampaikan pada Seminar dalam Rangka HUT ke 36 Jurusan Fisika STKIP Singaraja pada 1 hari Minggu 5 Nopember 2000. 
Ardana, Nengah. 1999. Hubungan antara Motivasi Belajar dan Pola Pemberian Tugas dengan Prestasi Belajar Bidang Studi Fisika pada Siswa SMP Negeri 1 Denpasar. Skripsi. IKIP Mahasaraswati Tabanan.

Ayu, Emi Yuliani, dkk. 2018. Penerapan Pembelajaran Quick On The Draw Padamateri Laju Reaksi Untuk Meningkatkan Aktivitas Belajar Siswa. Jurnal Pendidikan Kimia Indonesia Volume 2 Nomor 1.

Lestiyaningsih, Herdika, dkk. 2013. Penerapan Pembelajaran Quick On The Draw Untuk Meningkatkan Hasil Belajar Matematika Pada Sub Pokok Bahasan Aritmetika Sosial Siswa Kelas VII F Semester Ganjil SMP Negeri 10 Jember Tahun Ajaran 2012/2013. Jurnal Kadikma, Vol. 4, No. 2, hal 39-48.

Sthephani, Aulia. 2017. Penerapan Model Kooperatif Dengan Teknik Quick On The Draw Untuk Meningkatkan Hasil Belajar Matematika Siswa Kelas VII5 SMP Negeri 22 Pekanbaru. Jurnal Penelitian dan Pembelajaran Matematika Volume 5 Nomor $1 .$. 